\title{
Commentary: Can a health care quality lens clarify transfusion practice in perioperative cardiac surgery?
}

\author{
Joseph M. Bednarczyk, MD, MSc, FRCPC, ${ }^{\mathrm{a}, \mathrm{b}}$ and Rakesh C. Arora, MD, PhD, FRCSC ${ }^{\mathrm{b}, \mathrm{c}}$
}

\author{
From the Departments of ${ }^{\mathrm{a}}$ Medicine and ${ }^{\mathrm{c}}$ Surgery, Max Rady College of Medicine, University of Manitoba, Winnipeg, \\ Manitoba, Canada; and ${ }^{\mathrm{b}}$ Cardiac Sciences Program, St. Boniface Hospital, Winnipeg, Manitoba, Canada. \\ Neither author received funding support for this editorial. \\ Disclosures: Authors have nothing to disclose with regard to commercial support. \\ Received for publication Feb 15, 2019; accepted for publication Feb 18, 2019; available ahead of print March 28, \\ 2019. \\ Address for reprints: Joseph M. Bednarczyk, MD, MSc, FRCPC, Room T258, Old Basic Sciences Building, 770 \\ Bannatyne Ave, Winnipeg, Manitoba R3T 2N2 Canada (E-mail: joseph.bednarczyk@gmail.com). \\ J Thorac Cardiovasc Surg 2020;159:974-5 \\ $0022-5223 / \$ 36.00$ \\ Copyright (c) 2019 by The American Association for Thoracic Surgery \\ https://doi.org/10.1016/j.jtcvs.2019.02.070
}

Red blood cell transfusion occurs with disproportionate frequency in perioperative cardiac surgical care, as evidenced by large registry analyses in the United States and Canada. ${ }^{1,2}$ As high users of a costly and limited resource with potential risks, it is paramount that we incorporate the best available evidence into patient care. The Transfusion Requirements in Cardiac Surgery Trial (TRICS III) is the largest trial to date to examine a restrictive (hemoglobin $<75 \mathrm{~g} / \mathrm{dL}$ ) versus a liberal (hemoglobin $<95 \mathrm{~g} / \mathrm{dL}$ ) transfusion trigger in cardiac surgical patients. ${ }^{3}$ Compared with previous related trials, the TRICS III included far more patients, examined a patient-centered clinically relevant primary outcome, performed the intervention through the continuum of the patient perioperative journey, and had excellent protocol adherence in the respective treatment arms. While this is a major accomplishment in its own right, the trial was also able to recruit ahead of its estimated rate.

When TRICS III was incorporated into an updated metaanalysis of 13 trials comparing restrictive versus liberal transfusion in more than 9000 cardiac surgical patients, the risk ratio for mortality was essentially $1 .^{4}$ In clinical practice, however, the decision to transfuse red blood cells is often based not exclusively on the hemoglobin concentration but also on best available physiologic indicators of endorgan tissue oxygenation. ${ }^{5}$ Nonetheless, with literature converging on an "answer" that restrictive transfusion in cardiac surgery is at least as safe as a liberal approach, new questions arise: Is routine transfusion to a liberal hemoglobin target in cardiac surgical care simply wasteful? To what extent can we justify individualized patient-level decision making in light of recent evidence and with mounting pressures to be stewards of limited health care resources? In this issue of the Journal, Hensley and colleagues ${ }^{6}$ take a unique vantage point by applying principles of health care quality management to answer these questions.

This review crystallizes our knowledge on transfusion practice in 3 ways. First, it provides a necessary overview of the it just right?"

\section{References} 2133-44.

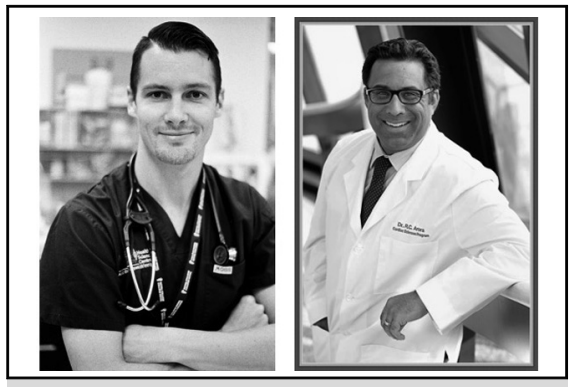

Joseph M. Bednarczyk, MD, MSc, FRCPC (left), and Rakesh C. Arora, MD, PhD, FRCSC (right).

\section{Central Message}

Should we use liberal or restrictive hemoglobin triggers for blood transfusion after cardiac surgery? Can we get it "just right"?

See Article page 971 .

blood transfusion trials in cardiac surgery to date and highlights the unique features of TRICS III that place it at the apex of this body of literature. Second, it challenges the common dogma that the targeted hemoglobin level should approximate the patient's age. As Hensley and colleagues ${ }^{6}$ note, in the 6-month follow up investigation by Mazer and colleagues, ${ }^{7}$ both the noninferiority between treatment groups for the primary outcome and the adverse effect of liberal transfusion in those with more advanced age persist. Finally, this work considers transfusion practice related to value-added activity for the patient and overall health care system, and in doing so brings us closer to answering the question "Can we get

1. Chiavetta JA, Herst R, Freedman J, Axcell TJ, Wall AJ, van Rooy SC. A survey of red cell use in 45 hospitals in central Ontario, Canada. Transfusion. 1996;36:699-706.

2. Bennett-Guerrero E, Zhao Y, O'Brien SM, Ferguson TB Jr, Peterson ED, Gammie JS, et al. Variation in use of blood transfusion in coronary artery bypass graft surgery. JAMA. 2010;304:1568-75.

3. Mazer CD, Whitlock RP, Fergusson DA, Hall J, Belley-Cote E, Connolly K, et al; TRICS Investigators and Perioperative Anesthesia Clinical Trials Group. Restrictive or liberal red-cell transfusion for cardiac surgery. N Engl J Med. 2017;377:

4. Shehata N, Mistry N, da Costa BR, Pereira TV, Whitlock R, Curley GF, et al. Restrictive compared with liberal red cell transfusion strategies in cardiac surgery: a meta-analysis. Eur Heart J. August 10, 2018 [Epub ahead of print].

5. Patel NN, Murphy GJ. Evidence-based red blood cell transfusion practices in cardiac surgery. Transfus Med Rev. 2017;31:230-5. 
6. Hensley NB, Brown CH, Frank SM, Koch CG. The Goldilocks principle and perioperative red cell transfusion: overuse, underuse, getting it just right. J Thorac Cardiovasc Surg. 2020;159:971-3.
7. Mazer CD, Whitlock RP, Fergusson DA, Belley-Coté E, Connolly K, Khanykin B, et al. Six-month outcomes after restrictive or liberal transfusion for cardiac surgery. N Engl J Med. 2018;379:1224-33. 